PNL-8871

UC-510

\title{
Organic Layer Sampling for SST 241-C-103 Background, and Data Quality Objectives, and Analytical Plan
}

T. W. Wood

C. E. Willingham

J. A. Campbell

August 1993

Prepared for

the U.S. Department of Energy

under Contract DE-AC06-76RLO 1830

Pacific Northwest Laboratory

Richland, Washington 99352 


\section{Executive Summary}

A layer of organic material floating on the surface of the high level radioactive waste in single-shell tank 241-C-103 has been declared an Unreviewed Safety Question (USQ). This designation is motivated by concern that a "pool fire" in this layer could release radioactive material from the tank. This layer is believed to consist largely of Tri-Butyl Phosphate (TBP) and Normal Paraffin Hydrocarbon (NPH), but its composition is not known definitively. Resolution of this USQ hinges on a more complete and detailed understanding of the flammability potential of this layer and vapors that could evolve from it, and to a lesser extent on the propagation and energetics of such a pool fire if initiated, and the source-term associated with a release event following a pool fire.

This increased understanding of the risk posed by this layer in turn requires better information on its composition. This report documents a Data Quality Objectives (DQO) study conducted to define this information in detail. This study was conducted by staff from Westinghouse Hanford Company and Pacific Northwest Laboratory between February and May of 1993. This study involved identification of several questions relevant to USQ closure, definition of analytical measures that would be definitive for their resolution, and optimization of a sampling and analytical plan to obtain these measurements. Other safety issues for this tank, including those associated with vapor toxicity, were not intended to be definitively addressed by this plan, although data from these dip samples will prove of some value in studies of these issues.

The resulting plan as set forth in this report calls for the collection of $4100-\mathrm{mL}$ dip samples from the layer, and several sets of analysis including Gas Chromatography Mass Spectrometry (GC/MS) for organic constituents of liquid and vapor evolving from it, flashpoint measurements, Ion Chromatography to characterize oxidizers, radiochemistry for selected radionuclides, Differential Scanning Calorimetry and Thermal Gravimetric Ana''sis (DSC/TGA) for energetics, and measurement of viscosity to help establish the degree of homogeneity of the layer. In addition to the summary plan presented in the report, a detailed laboratory procedures document is included as an appendix. 


\section{Contents}

Executive Summary $\quad \ldots \ldots \ldots \ldots \ldots \ldots \ldots \ldots \ldots \ldots \ldots \ldots \ldots \ldots$ iii

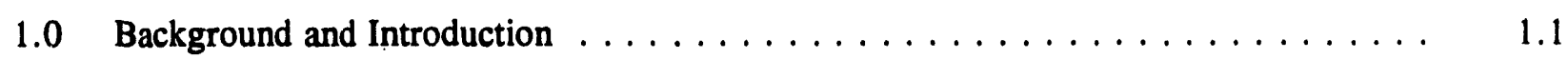

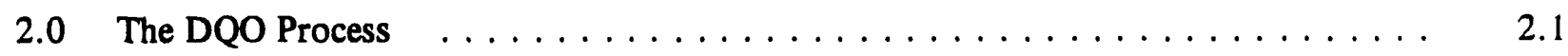

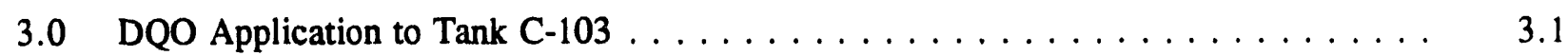

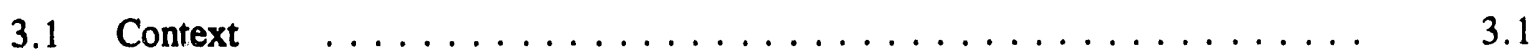

3.1.1 Relevant Issues and Sampling Opportunities $\ldots \ldots \ldots \ldots \ldots \ldots . . \ldots \ldots$

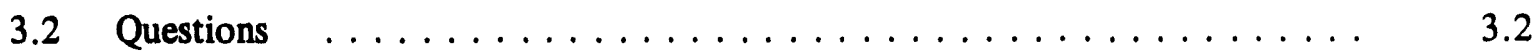

3.2.1 Specific Questions Identified . . . . . . . . . . . . . . . 3.2

3.2 .2 Relation to Issues $\ldots \ldots \ldots \ldots \ldots \ldots \ldots \ldots \ldots \ldots$

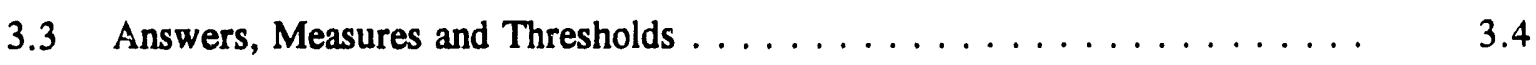

3.3.1 Root Questions $\ldots \ldots \ldots \ldots \ldots \ldots \ldots \ldots \ldots \ldots \ldots \ldots$

3.4 Recommended Analytical Plan $\ldots \ldots \ldots \ldots \ldots \ldots \ldots \ldots \ldots$

3.4.1 Sample Quantity Requirements $\ldots \ldots \ldots \ldots \ldots \ldots \ldots \ldots$

3.4 .2 Priorities for Analysis $\ldots \ldots \ldots \ldots \ldots \ldots \ldots \ldots \ldots$

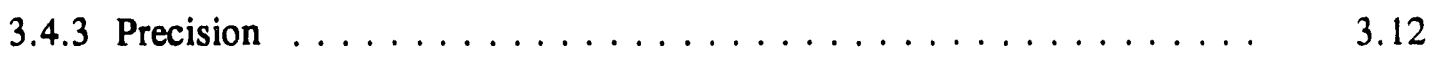

4.0 Summary and Conclusions $\ldots \ldots \ldots \ldots \ldots \ldots \ldots \ldots \ldots \ldots \ldots$

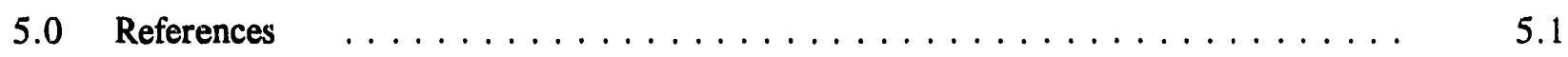

Appendix A - DQO Participants $\ldots \ldots \ldots \ldots \ldots \ldots \ldots \ldots \ldots \ldots \ldots \ldots \ldots$

Appendix B - Tank C-103 Dip Sample Analytical Plan . . . . . . . . . . . B.1 


\section{Tables}

3.1 Initial Questions and Issues in the DQO Process for Tank C-103

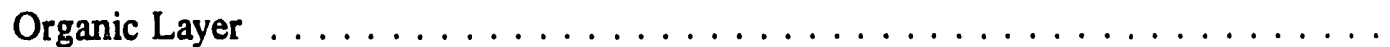

3.2 Root Questions in the DQO Process for Tank C-103

Organic Layer

3.3 Recommended Analytical Plan for Dip Samples from the Organic Layer of Tank C-103 


\subsection{Background and Introduction}

This report documents the derivation of Data Quality Objectives (DQOs) for sampling a floating organic layer in single-shell tank (SST) 241-C-103. This activity was undertaken by the Data Requirements, Evaluation, and Management (DREAM) project in late February 1993 at the request of the Westinghouse Hanford Company (WHC) Tank Safety Organization. The principal motivation for the sampling and DQO activities is to provide support for the resolution of an Unreviewed Safety Question (USQ) involving the presence of an organic layer in a SST. The goal of the DQO process for Tank C-103 is to develop an integrated, optimized dip-sample analytical plan that will allow for the resolution of the USQ.

The derivation of DQO was conducted at four meetings held at Pacific Northwest Laboratory (PNL) February 26, March 8, May 10 and May 27, 1993, involving seven WHC staff, eight PNL staff, and observers from Department of Energy-Richland Field Office (DOE-RL) and Mid-Columbia Engineering Technical Services, Inc. (MACTEC). The first of these meetings included a very brief introduction to the steps involved in the DQO process and some lessons learned in prior applications to Tank SST-C-106, but involved no formal DQO training per se. The first meeting covered the context surrounding this tank, derived a list of 11 specific questions felt to be relevant for the DQO, and established a target schedule for the remainder of the DQO activity. The second meeting explored possible answers to these questions, defined measures that would be definitive for their resolution, and determined the relevant quantitative thresholds, sensitivity requirements, and accuracy requirements associated with these measurements. During the second meeting, the 11 questions were reduced to 8 questions. The third meeting continued to focus and consolidate the remaining issues, resulting in three "root" questions. A fourth meeting was held to discuss USQ and vapor sampling issues. A list of participants is provided in Appendix A.

This report documents the results and, to a limited extent, the conduct of this DQO application. More detailed meeting minutes are available for those who wish to examine the DQO derivation logic in greater depth. The recommended analytical plan resulting from this DQO and documented in this report will be followed by specific laboratory procedure development prior to analysis of the samples. The report is organized according to the various DQO steps, with several of the latter steps grouped for discussion purposes. 


\subsection{The DQO Process}

The DQO process is a structured, stepwise approach to the definition of data requirements. It was developed at the U.S. Environmental Protection Agency (EPA) in the 1980s and has been applied to numerous Superfund site characterization planning problems. The process consists of seven steps: 1) context, 2) questions, 3) answers, 4) measures, 5) error tolerances, 6) decision rules, and 7) sampling plan optimization (Blacker and Goodman 1992). This process is being applied and, to some extent, adapted to the Tank Waste Remediation System (TWRS) safety and remediation planning domains within the DREAM project. The current application is the second within TWRS and is very restricted in the scope of sampling and analysis activities that it seeks to define and optimize. In the longer term, DQO activities within TWRS will be organized around generic issues rather than single sampling events, thus allowing for a more efficient application of the logic in planning the characterization planning program.

Some prior experience in applying the DQO process in TWRS was available at the outset of the C-103 DQO. A pilot DQO study on a core-sample event for C-106 had been underway for several months and had resulted in several important lessons for the current study. This experience revealed that the DQO process within TWRS must accommodate multiple questions or issues for a single sampling event and that questions should be as specific as possible and not "open-ended." Decision rules should be specified prior to definition of error tolerances. In cases where the questions are exploratory in nature and decision rules cannot be well formulated, the definition of error tolerances is subjective.

To the extent possible, this process and these lessons were applied in the C-103 DQO study. The emphasis, however, was to focus the questions on the USQ and achieve consensus on the analytical plan for the samples, rather than precise adherence to the mechanics of the DQO process.

A general observation on the conduct of this DQO is that most of the participants have devoted considerable prior thought to the relevant safety issues arising from the organic layer in C-103. As a consequence, the context was relatively well known and required only documentation. The relevance of the questions was high and generally obvious, and questions were framed in a way that led immediately to the specifics of measurement conditions in the laboratory. Since the questions had been formulated by the meeting participants in very specific analytical terms, it was later in the DQO process that the underlying or "root" questions were articulated and agreed upon. 


\subsection{DQO Application to Tank C-103}

\subsection{Context}

Tank C-103 is a SST that has been designated as an organic tank and placed on the Hanford Waste Tank Safety Watch List. The USQ is the presence of an organic layer floating on the aqueous material in the tank (Grantham 1992). Although there may be several safety issues related to the organic pool, the assumption made in the DQO process was that flammability and issues related to the potential for and consequences of a fire fueled by the organic pool were of primary importance. Dip samples from this organic layer were scheduled to resolve flammability questions. This layer is between 2 -in. and 16-in. thick. This sample will be conducted using a bottle-on-a-string method. The appropriate analytical plan for these samples had not been previously determined, leading to the DQO activity. The existence of organic layers in double-shell tanks (DST) has been addressed in the Safety Analysis Reports (SARs), and there are no USQs related to these organic layers.

Numerous transfers of waste to and from Tank C-103 have taken place. The material in this tank is thought to have a level of $\mathrm{pH}$ between 9.8 and 10.5 based on a previous core-sample analysis of the tank. This analysis also shows that the organic layer contained Tri-Butyl Phosphate (TBP) and Normal Paraffin Hydrocarbon (NPH), but analytical procedures were not sufficient to completely identify organic species in the layer. There has been a history of exposures to noxious vapors in the $\mathrm{C}$-farm. Some or all of these events are suspected to have originated from tank C-103. Fogs of some type have been observed in the tank headspace.

\subsubsection{Relevant Issues and Sampling Opportunities}

From this context, there arise five issues relevant to dip sampling: 1) pool fire, 2) aerosol/vapor flammability, 3) noxious vapors, 4) organics, and 5) criticality.

In addition to these multiple issues, several characterization opportunities could furnish information on these concerns. Dip samples of the organic layer and vapor samples from the tank headspace of tank C-103 are scheduled to be taken on the same day. It is important that all vapor/aerosol sampling activities be completed before taking the dip samples. Although not currently planned, additional dip samples could be acquired at a later clate.

During DQO discussions, concerns were raised on how to resolve discrepancies, if they were is occur, between vapor measurements taken on the dip samples and actual aerosol measurements made in the tank headspace. As a result of these concerns, questions about aerosol measurements were not included in the later stages of this DIOO process. The aerosol measurements of the tank hearispace are, the definitive source for vapor information for tank C-103 and are being supported in a parailel DQO 
activity. Information from measurements of vapors evolving from the dip samples will be carefully evaluated with respect to the aerosol results. However, information from measurements of vapors evolving from dip samples are essential for resolving the USQ.

In preliminary discussions on the extent and content of this DQO activity, the multiple issue/ multiple opportunity space was considered as potential scope for the DQO activity. This discussion resolved to a scope definition in which pool-fire issue was given priority, and other issues would be included on an opportunistic basis. The scope of the DQO activity for tank C-103 was restricted to issues relating to the next scheduled dip samples from the organic layer. Excluded from this DQO process were additional dip samples of the organic layer, vapor samples, and core samples.

\subsection{Questions}

The first step in the DQO process (Blacker and Goodman 1992) is to articulate relevant questions for which a definitive answer is sought from the data to be taken. This process is analogous to the hypothesis formulation step in experimental design, but it typically embodies less explicit phenomenological content than exploratory science and is focused on questions with immediate practical significance. During the initial DQO meeting held in February 26, 1993, candidate questions were generated under "brainstorming" rules, (i.e., any member in the group was free to pose questions felt to be important). While there was some discussion of the framing or phrasing of these questions, no initial attempt was made to reach a group consensus on the inclusion or priority of the questions because of time constraints and the DQO process itself. The questions described in the following section (Section 3.2.1) are from all four meetings.

\subsubsection{Specific Questions Identified}

1. Organic Content - This question was originally posed in the open-ended form "What organic constituents does the layer contain?" Attempts to specify a list of important constituents identified kerosine, TBP, n-Butyl alcohol, and hexone, but it was quickly concluded that such a list, if complete, would include an unmanageable number of compounds. In order to add some specificity, the question was rephrased as "What organic constituents are identified by Gas Chromatography/Mass Spectrometry (GC/MS)."

2. Flash Point and "Flammability" - This question was originally framed as "How flammable is the organic layer?" After preliminary discussion of the meaning of flammability, it was decided that the principal question of interest concerned the conditions sufficient for ignition. The question was rephrased as "What is the flash point of the material in the organic layer?" The related question "How flammable is the material?" was retained in the original question list to capture a broader 
interest in the behavior of a fire in the material after ignition (e.g., rate of propagation, energy release, etc.). Subsequent discussions concluded that these questions would ultimately be addressed by modeling, based on chemical composition.

3. Vapor Flammability - This question was originally posed as "Is the vapor generated from the dip sample flammable?" Discussion of the question in this form concluded that it was identical to question 2 , since the vapor phase is involved in any combustion. A meaningful distinction between the two questions was maintained-if the vapor flammability question specified temperature conditions for the evolution of vapors. This question was rephrased as "Is the vapor generated from the sample at (sample) temperatures of $42^{\circ} \mathrm{C}, 70^{\circ} \mathrm{C}$, and $100^{\circ} \mathrm{C}$ flammable?" thus incorporating the temperature-dependent volatility of the material in this question. It is important that this question was not reduced to that of a flash point--even one in which ignition and vapor evolution temperatures were independently controlled.

4. Inorganic Constituents - This question was originally phrased as "What are the important inorganic constituents in the organic layer?" Discussions concluded that importance was associated in this context with oxidizing compounds, and that $\mathrm{NO}_{2}^{-}$and $\mathrm{NO}_{3}^{-}$were the most likely candidates to be present in significant concentrations. Latter discussions concluded that the greatest fraction of any oxidizers present in the organic layer would be dissolved in the water contained in this layer.

5. Dose and Criticality - This question was originally "What are the radionuclides important to dose or criticality"? Although not explicitly stated in the question, the inventory of interest was implicitly that in the organic layer and not on other waste materials in this tank. Discussions showed that the context from which these two concerns arose was quite different, and that the question should be separated into one dealing with dose and the other dealing with criticality. The question of dose-generating nuclides arises from a scenario in which potentially respirable soot is released from the tank ventilation system during or after a pool fire. Although no specific credible scenario was identified for criticality, the possibility of saturation of the organic material with plutonium was recorded. Clearly, if criticality were a concern it would be in-situ rather than in the combustion products. Studies of critical concentrations in Dibutyl Butyl Phosphate (DBBP) (Davenport and Thompson 1982) show plutonium critical mass and concentrations similar to water and state that TBP systems "should have nearly the same criticality parameters."

The scenario in which a pool fire consumes a significant fraction of this layer could result in concentrations of the fissile inventory within the tank. This mechanism, or other mechanisms that could concentrate the fissile inventory at the organic-aqueous interface, would be investigated only if the fissile inventory measured in the layer were greater than $1 \mathrm{~g} / \mathrm{L}$.

6. Deflagration of Dry Material - The question "Can dry sample deflagrate when heated?" was raised in connection with scenarios in which the aqueous phase of the organic layer evaporates. The combustibility of this residual material is independent of that for the layer in its current form. 
7. Vapor Constituents - The recorded version of this question from the first meeting was "What vapor constituents are in the dip samples?" This question was subsequently interpreted to mean "What are the constituents of the vapor evolving frum the samples?" In this form, the question leads to the same set of measurements as does question 3, and this question was dropped from the DQO.

8. Stagnation/Mixing - The question "Is the organic layer stagnant or thermally mixed" was posed as potentially relevant to temperature gradients within the layer and thus the vapor evolution rate. This question was rephrased to relate to viscosity at the DQO stage when measures were selected.

9. Aerosol Formation - This question was originally, "What is the aerosol capability of the material?" Answering this question is relevant to understanding the evolution of a pool-fire event and, independently, in determining the context of the fogs in this tank. In the former context, the question on the water content of the aerosol would be important with regard to its flammability. Discussions of possible answers to this question concluded that the vapor pressures of various constituents could provide some information on this question. However, the definitive measurements related to aerosols were the vapor samples scheduled to be taken in conjunction with the dip samples from the organic layer.

10. Toxic Volatile Constituents - This question was posed in the form "What are the toxic volatile constituents in the sample?" This question is relevant to the noxious vapor issue in C-farm, its overall health significance, and its association with this particular material in C-103. Acetonitrile was identifled as a potential toxic constituent of concern. Two additional questions were raised during the third meeting. These questions were "Are there any toxic constituents in the liquid that are not found in the vapor phase?" and "What does the act of heating the sample do to the constituents and concentrations of the sample?"

11. Vapor Toxicity - Related to question 10 was the question "What toxic constituents form above a heated sample?" This question combines the issues of temperature-dependent volatility and toxicity. Discussions during the "measures" phase of the DQO revealed that this question generated no measurement requirements beyond those associated with question 3 .

\subsubsection{Relation to Issues}

Many of the questions identifled relate to more than a single relevant issue. Table 3.1 shows a list of each question and corresponding issues identified during the initial DQO stages.

\subsection{Answers, Measures, and Thresholds}

The next step in the DQO process for Tank C-103 dip sampling was to examine possible answers for those questions identified during the initial meeting as described in Section 3.2. During the March 8, 1993, meeting, answers to each of these questions were explored to help focus the DQO, 
Table 3.1. Initial Questions and Issues in the DQO Process for Tank C-103 Organic Layer

\begin{tabular}{|c|c|}
\hline Question Key & Issues \\
\hline $\begin{array}{l}\text { 1. What organic constituents are identified by GC/MS? } \\
\text { Kerosene, TBP, n-butyl alcohol, hexone, water }\end{array}$ & Pool Fire, Aerosol/Vapor Flammability, and Noxious Vapors \\
\hline $\begin{array}{l}\text { 2. What is the flash point of the material in the organic layer? } \\
\text { 2A. How flammable is the material? }\end{array}$ & Pool Fire \\
\hline $\begin{array}{l}\text { 3. Is the vapor generated from the dip sample fiammable? Is the } \\
\text { vapor generated from the sample at (sample) temperatures of } \\
42^{\circ} \mathrm{C}, 70^{\circ} \mathrm{C} \text {, and } 100^{\circ} \mathrm{C} \text { flammable? }\end{array}$ & Aerosol/Vapor Flammability \\
\hline $\begin{array}{l}\text { 4hat are the important inorganic constituents in the organic } \\
\text { layer? }\end{array}$ & Organics, Criticality \\
\hline $\begin{array}{l}\text { What are the radionuclides important to dose or } \\
\text { criticality? }\end{array}$ & Pool Fire, Aerosol/Vapor Flammability and Criticality \\
\hline 6. Can dry samples deflagrate when heated? & Organics \\
\hline $\begin{array}{l}\text { 7. What vapor constituents are in the dip samples? What are the } \\
\text { constituents of the vapors evolving from the samples? }\end{array}$ & Aerosoi/Vapor Flammability, Noxious Vapors \\
\hline $\begin{array}{l}\text { 8. Is the organic layer stagnate or thermally mixed? What is the } \\
\text { viscosity at the stage when measurements were selected? }\end{array}$ & Pool Fire \\
\hline 9. What is aernsol capability of the material? & Aerosol/Vapor Flammability \\
\hline $\begin{array}{l}\text { 10. What are the toxic volatile constituents in the sample? Are } \\
\text { there any toxic constituents in the liquid that are not found in } \\
\text { the vapor phase? }\end{array}$ & Noxious Vapors \\
\hline 11. What toxic constituents form above a heated sample? & Noxious Vapors \\
\hline
\end{tabular}


clarify the various questions, and assist in defining the relevant measures and thresholds. This process is briefly described here with emphasis on the selected measures and thresholds. In some cases, considerations of experimental precision bear on the selection of methods.

1. Organic Content - As noted in Section 3.2, the possible number of compounds present in this layer requires a screening approach - thousands of compounds could be present and many of them could be significant to the various issues. A purge and trap (PeT) analysis of the sample will identify compounds in the 1-50 amu range while a GC/MS analysis of the sample will identify compounds with molecular weights of 50-2000 amu. It was agreed that such a screening would first be conducted to resolve the relative abundance of sample constituents, followed by an analysis (incorporating a standard) to measure concentrations. Although no specific concentration thresholds were identified, this measurement will identify compounds present in much smaller amounts than would be significant to combustion (probably in the range of $0.1 \%-1 \%$ ) and will probably be adequately sensitive for the toxicity issue as well.

2. Flash Point and Flammability - The relevant measure for flash point is the temperature at which the sample ignites. Beyond this simple and universally accepted proposition, there was considerable discussion on the philosophical approach to determination of ignitability of the material. One approach involves reliance on the experimental measurement of flash point using one of several possible types of apparatus (Pensky-Martin, Setaflash, etc.). The alternative to this experimental approach is a modeling study based on the compositions identified in the GC/MS analysis. The acceptability of the experimental approach hinges on the reproducibility of this measurement. Several sources were quoted that established precision in the range of a few percent. It was agreed that a precision of $\pm 5^{\circ} \mathrm{C}$ should be sufficient and that the experimental measurement of flash point would be the definitive measurement for ignitability, provided that the calibration studies using at least one ASTM standard material were conducted in parallel with the moasurements. It was also felt to be important to measure flashpoint of the material as sampled (including aqueous fraction) and after stripping of the aqueous fraction from the material.

No single measurement was defined that captured the "flammability" in the broader sense of the sustainability, propagation, and energy release expected in a pool fire if ignition were to occur. It was agreed that this broader question would be best addressed in a modeling framework using the GC/MS results.

3. Vapor Flammability - As noted in Section 3.2, the possibility exists that vapor ignition could occur in the tank headspace independently of ignition at the surface of the organic layer. It was agreed that this possibility would be addressed with modeling studies based on the $\mathrm{GC} / \mathrm{MS}$ results for vapors evolving from sample material at temperatures ranging from $40^{\circ} \mathrm{C}-100^{\circ} \mathrm{C}$. 
4. Inorganics - The measures of significance for inorganics are concentrations of anions and cations. It was agreed that Ion Chromatography (IC) would be the appropriate measurement technique for anions and that Inductively Coupled Plasma-Optical Emission Spectroscopy (ICP-OES) would be the preferred technique for cations. Both of these techniques provide sensitivity to concentrations far below thresholds of significance in combustion (conservatively from $0.1 \%-1 \%$ ). Based on previous studies of tank wastes, the presence of peroxides (an indicator of oxidizers in the organic lay (1) was identified as a consideration, and the "Battelle Peroxide" procedure (iodometric titration) was recommended as an additional measurement for peroxides.

5. Dose and Criticality - There was considerable discussion of the appropriate measurements on which to base SAR dose calculations. Although it was agreed that consequence measures (bounding limits to dose consequence) alone would probably not be sufficient to resolve the pool fire issue and that the SAR strategy would be to limit event probability, reasonably accurate measurements of the dose potential from pool-fire combustion products were felt to be important. It was generally agreed, in this respect, that total alpha would not be a sufficient measure for dose, and that independent measurements of transuranics (at least ${ }^{235} \mathrm{U},{ }^{209} \mathrm{Pu},{ }^{240} \mathrm{Pu},{ }^{241} \mathrm{Am}$ ) and ${ }^{137} \mathrm{Cs}$ and ${ }^{90} \mathrm{Sr}$ might be required. The measurement strategy selected was that the cesium and strontium isotopes would be measured, by GEA (Cs) and $\beta$ radio-chemistry $(\mathrm{Sr})$, and that transuranics would be independently measured if total alpha exceeded $1 \times 10^{-8} \mathrm{Ci} / \mathrm{L}$.

A calculated set of $k_{\text {eff }}$ predictions would be the appropriate measurement for criticality safety in the organic layer. Such calculations would require measurements of moderator (including organics and water) distributions on a small spatial scale and accurate measurements of concentrations of poisons (Boron, Iron, and several others) in the PPM range. In addition, accurate measurements of ${ }^{235} \mathrm{U},{ }^{239} \mathrm{Pu}$, and ${ }^{240} \mathrm{Pu}$ and definitive geometry of the layer and surrounding materials would be required. While it was agreed that a definitive criticality study for the organic layer was beyond the scope of this DQO, it was decided to incorporate a minimal screening measurement to determine the need for additional measurements and criticality studies. This measurement will involve a plutonium concentration calculation made by measuring total alpha and assuming it is all ${ }^{239} \mathrm{Pu}$. If this amount exceeds $1 \mathrm{~g} / \mathrm{L}$, then the ${ }^{239} \mathrm{Pu} /{ }^{240} \mathrm{Pu}$ ratio, total uranium, and ${ }^{241} \mathrm{Am}$ will be measured in order to determine the plutonium concentration.

6. Deflagration of Dry Material - The definitive measurement for this question was agreed to be the energy of reaction as measured by Differential Scanning Calorimetry/Thermal Gravimetric Analysis (DSC/TGA). This measurement will be conducted on dried constituents from the aqueous phase of the sample. A limit of $75 \mathrm{cal} / \mathrm{g}$ was established as the threshold of concern for this measurement.

7. Vapor Constituents - As noted in Section 3.2, this question was dropped as a separate issue, since it led to the same analysis as did question 3. 
8. Stagnation and Mixing - The measurement of viscosity of the material will be used to bound the degree of thermal mixing. It was agreed that a threshold of 1 centipoise was appropriate for this measurement, since values below this would ensure essentially complete mixing in the organic layer.

9. Vapor Toxicity - The two questions relating to vapor toxicity were agreed to be adequately addressed by the GC/MS measurements conducted for question 3. The sensitivity of the GC/MS instrument is assumed to be adequate for this measurement.

\subsubsection{Root Questions}

During the third meeting, the questions, answers, and measures identified and described during the first two meetings were further grouped under three basic root questions. These questions are 1) Can a fire start? 2) Will a fire be sustained? and 3) What are the resulting radiological-and toxicologicalsource terms from a fire? Discussion also focused on addressing vapor-program and USQ concerns in relation to the dip-sample activities for tank C-103. Table 3.2 shows the list of concerns relating to each root question.

\subsection{Recommended Analytical Plan}

The measurements described in Section 3.3 were incorporated into a recommended analytical plan by estimating sample and archival requirements, assigning priorities for analysis, and assessing the accuracy requirements of the measurements in relation to standard laboratory practice. Table 3.3 summarizes this plan for each of the relevant questions. Information concerning specific analyses and procedures was obtained from both PNL and WHC laboratories. A more detailed analytical plan for the analysis of tank C-103 dip samples is shown in Appendix B.

\subsubsection{Sample Quantity Requirements}

Sample quantity requirements were estimated for each set of measurements and are shown in the last row of Table 3.3. Some of the tests, including the transuranics measurements and DSC/TGA, can be done with re-used material from the vapor evolution/measurement for question 3. Accounting for this reuse, the total sample requirements are estimated to be $250-275 \mathrm{~mL}$. Allowing for some incomplete recovery and archive requirements, it was decided to take four $100-\mathrm{mL}$ bottles of sample.

\subsubsection{Priorities for Analysis}

Since the sample quantity requirements are within the range of quantity easily obtainable, analytical priorities were addressed only in the sense of identifying the highest priorities. Since the reproducibility of flash-point measurements is also at issue and establishing this could require several replications 
Table 3.2. I ot Questions in the DQO Process for Tank C-103 Organic Layer

\begin{tabular}{||l|l|}
\hline \multicolumn{1}{|c|}{ Root Question } & \multicolumn{1}{|c|}{ Initial Topics } \\
\hline \hline 1. Can a fire start? & $\begin{array}{l}\text { Organic Content } \\
\text { Flashpoint and Flammability } \\
\text { Stagnation and Mixing }\end{array}$ \\
\hline 2. Will a fire be sustained? & $\begin{array}{l}\text { Organic Content } \\
\text { Flashpoint and Flammability } \\
\text { Inorganics } \\
\text { Stagnation and Mixing }\end{array}$ \\
\hline Source-terms from a fire? & $\begin{array}{l}\text { Organic Content } \\
\text { Vapor Flammability } \\
\text { Dose } \\
\text { Criticality } \\
\text { Deflagration of Dry Material } \\
\text { Stagnation and Mixing }\end{array}$ \\
\hline
\end{tabular}


Table 3.3. Recommended Analytical Plan for Dip Samples From the Organic Layer of Tank C-103

\begin{tabular}{|c|c|c|c|c|c|}
\hline Question & $\begin{array}{l}\text { 1. GC/MS for } \\
\text { Organics }\end{array}$ & $\begin{array}{l}\text { 1A. GC/MS with } \\
\text { Calibrated } \\
\text { Standard }\end{array}$ & $\begin{array}{l}\text { 2. Flashpoint } \\
\text { Tester }\end{array}$ & $\begin{array}{l}\text { 3. Vapor } \\
\text { Flammability }\end{array}$ & 4. Inorganics \\
\hline Comments & Screening analysis & Screen with standard & $\begin{array}{l}\text { Highest priority for } \\
\text { sample allocation. Obtain } \\
\text { both with and without } \\
\text { water }\end{array}$ & $\begin{array}{l}\text { Flammability of organic } \\
\text { vapors as a function of } \\
\text { temperature }\end{array}$ & $\begin{array}{l}\text { Aqueous layer } \\
\text { Organic layer (only if } \\
\text { greater than 1\%) }\end{array}$ \\
\hline Answers & $\begin{array}{l}\text { Preliminary evaluation of } \\
\text { relative abundance }\end{array}$ & $\begin{array}{l}\text { Quantitative evaluation of } \\
\text { compounds present }\end{array}$ & Flashpoint & $\begin{array}{l}\text { Calculated from } \\
\text { information obtained in IA }\end{array}$ & $\begin{array}{l}\text { anions, } \mathrm{NO}_{3}^{-}, \mathrm{NO}_{2}^{-}, \\
\mathrm{Cl}^{-}, \mathrm{F}, \mathrm{SO}_{4}^{-2}, \text { peroxide } \\
\text { (Battelle titration } \\
\text { procedure) }\end{array}$ \\
\hline Measures & $\begin{array}{l}\text { GC/MS: Relative } \\
\text { abundance of constituents; } \\
\text { presence of alkyl nitrates } \\
\text { will be investigated }\end{array}$ & $\begin{array}{l}\text { GC/MS: Concentration } \\
\text { measures }\end{array}$ & $\begin{array}{l}\text { Mini flashpoint tester } \\
\text { ASTM Pensky standard }\end{array}$ & $\begin{array}{l}\text { GC/MS analysis of vapors } \\
\text { at } 40^{\circ} \mathrm{C}-100^{\circ} \mathrm{C}\end{array}$ & $\begin{array}{l}\text { Ion chromatography } \\
\text { (anions), ICP-OES } \\
\text { (cations) }\end{array}$ \\
\hline Thresholds & N/A & N/A & N/A & N/A & Varies acconding to analyte \\
\hline Other & Purge/Trap for volatiles & & Not in hot cell & & \\
\hline $\begin{array}{l}\text { Amount of } \\
\text { Sample }\end{array}$ & \multicolumn{2}{|c|}{$10-15 \mathrm{~mL}$} & $\begin{array}{l}2 \mathrm{~mL} \text { mini flashpoint } \\
60 \mathrm{~mL} \text { ASTM Pensky }\end{array}$ & $100 \mathrm{~mL}$ & $10 \mathrm{~mL}$ \\
\hline
\end{tabular}


Table 3.3. (contd)

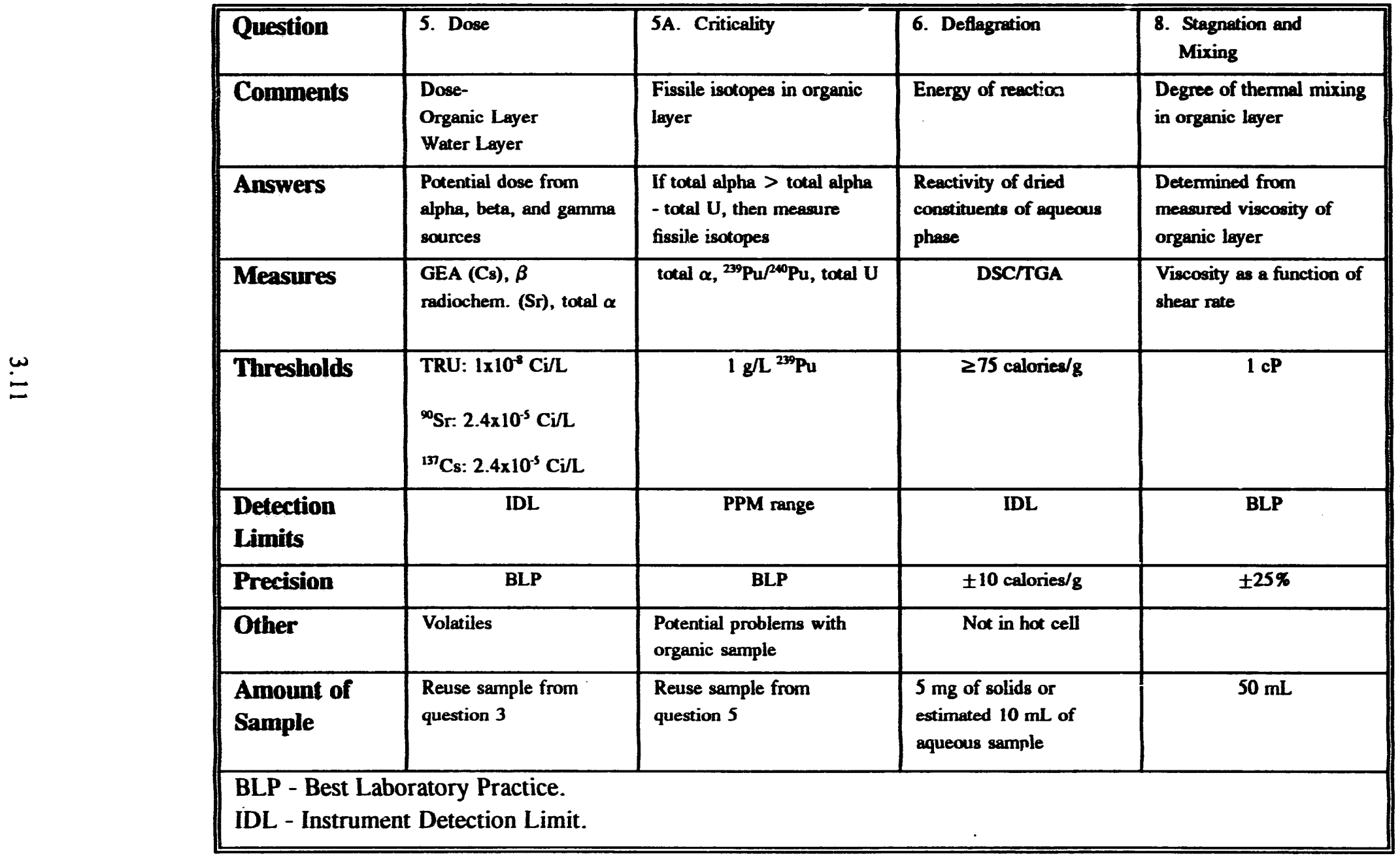


of the test, it may be desirable to conduct these measurements first. It was agreed that the flash-point measurements had the highest single priority, followed by the GC/MS on sample and the GC/MS on vapor constituents.

\subsubsection{Precision}

The precision available from the GC/MS measurements will generally be in the range of a few percent for organic constituents. This is far better than required for measurements related to the pool-fire issue and is generally sufficient for assessment of toxic constituents. Accuracy requirements for the flashpoint tests were established at a precision (standard error) of up to $5^{\circ} \mathrm{C}$ for the ASTM calibration standard(s) selected for use. It was agreed that the IC and ICP-OES analysis for inorganics would provide more than adequate precision for the inorganics measurements--requirements for this analysis are in the precision range of $15 \%$ - 20\% Relative Percent Difference (RPD) for duplicate samples. All other precision requirements are best laboratory practice (BLP). 


\subsection{Summary and Conclusions}

The DQO process was used to help focus and consolidate questions, answers, and measures related to proposed dip-sampling activities for tank C-103. The set of measurements was described in an analytical plan believed to be sufficient to resolve the organic layer USQ. The analytical plan is anticipated to provide useful information on other issues of aerosol/vapor flammability, noxious vapors, organics, and criticality. 


\subsection{References}

Agnew, S. F., P. Baca, and F. Bickl. Tank History Analysis - C-Farm and 103.C. IAUR, Los Alamos National Laboratory, Los Alamos, New Mexico.

Blacker, S. M., and D. Goodman. 1992. Data Quality Objectives Planning Process, Training Workshop. DOE-RL Operations Office, Richland, Washington.

Davenport, T. C., and J. K. Thompson. 1982. A Survey of Criticality Parameters Parameters for ${ }^{239} \mathrm{Pu}$ in Organic Media. ANS Transactions, Vol. 27, UCRL-53369, Lawrence Livermore National Laboratory, Livermore, California.

Grantham, R. R. 1992. Tank Farm SST Organics. Unreviewed Safety Question \#0192-ORG-TKS. Westinghouse Hanford Company, Richland, Washington. 
Appendix A

\section{DQO Participants}




\section{Appendix A}

\section{DQO Participants}

Tom Wood, PNL

Roger Bean, PNL

John Buck, PNL

Arlin Postma, WHC

Bob Marusich, WHC

Denis Strachan, WHC

Darby Stapp, WHC

Harry Babad, WHC

Kevin Bell, WHC

David Turner, WHC

Jim Huckaby, WHC

Robert Strebin, PNL

David Baldwin, PNL

Joel Tingey, PNL

Bob Wegeng, PNL

Joan Young, PNL

Mike Story, NISI

Jim Campbell, PNL
DREAM Program Manager (Meeting Chairman)

PNL Characterization Programs Manager

DREAM Project

Hazards Analysis on Tanks

Accident Analysis

Tank Safety Program Manager

PNL Systems Analyst (Facilitator)

WHC Data Evaluation Team Chairman

Characterization and Safety Technology

Environmental Assessment

Vapor/Aerosol Flammability

Chemistry Labs

Analytical Chemist

Physical Chemist

Tank Analyst

DREAM Data Requirements Task (Scribe)

Instrument Systems

PNL Analytical Plan 


\section{Appendix B}

\section{Tank C-103 Dip Sample Analytical Plan}




\title{
Appendix B
}

\section{Tank C-103 Dip Sample Analytical Plan}

\author{
By
}

J. A. Campbell

\section{Task 04 - Analysis of Dip Sample of Tank C-103}

A dip sample (bottle on a string) from the organic layer in tank C-103 is scheduled to be taken [under the Tank Vapor Program (IN2H)] in 1993. The layer will be sampled at its surface and approximately $2 \mathrm{ft}$ below the surface (in the aqueous layer).

The main focus of the analysis will be to obtain semiquantitative data for the understanding of flammability of the liquid vapor in tank C-103.

The work shal! be performed in accordance with the requirements of Pacific Northwest Laboratories (PNL) document MCA-033, Analytical Chemistry Laboratory Quality Assurance Plan, and Westinghouse Hanford Company (WHC)-SD-WM-QAPP-013, Rev. 0, Quality Assurance Project Plan for Tank 241-C-103 Vapor Characterization. Even though the work is research-oriented and developmental in nature, the quality of the data obtained shall be documented in the PNL-deliverable report. This reporting includes specifying procedures used; verifying proper operation of instruments; and listing standards, calibrations, and acceptance criteria, where applicable.

\section{Sample Considerations for C-103 Dip}

\section{Assumptions}

The following assumptions are made:

- 250-L organic sample

- four $100-\mathrm{mL}$ samples in glass with teflon-lined screw caps 
- organic layer can be separated and worked within hood

- sample volume required for viscosity measurements is $\leq 40 \mathrm{~mL}$

\section{Sample Handling and Analysis}

The sample handling and analysis requirements include the following:

1. One sample of mostly organic composition is held in a screw-capped container in a hot cell in reserve as a working archive.

2. Second sample is immediately separated quantitatively with sep sample, surveyed, and moved to hood ASAP.

3. Separated organic sample is immediately sub-sampled twice (10-mL subs) and stored in teflon-lined, glass screw-capped vials.

4. Begin a gas ch. Jmatography/mass spectrometry (GC/MS) screening of organic proceeds on the sample immediately after it is available. Next, purge-and-trap (P\& T) GC/MS on small subsample and direct GC/MS on neat sample, provided activity permits. If not, dilute sample just enough to permit sample removal to GC/MS lab.

5. Obtain water analysis on separateri organic layer immediately upon separation from water layer.

6. Measure the percent of $C$ and other elements, if possible.

7. Use screening results to design a quantitative, internal standard quantitation of all volatile and semi-volatile constituents in whole sample. Analyze phosphate esters by derivatization $\mathrm{GC} / \mathrm{MS}$, if possible.

8. Perform an atmospheric distillation of a $30-\mathrm{ml}$ sample. Stop the distillation at overhead temperatures corresponding to the boiling point of decane to enrich the liquid fractions and to separate the other components from the normal paraffin hydrocarbon (NPH) and tributyl phosphate (TBP). For use in a more detailed analysis, analyze residue for phosphate esters. Vacuum fractionate the residue. Analyze residue for phosphate esters.

\section{Task 0401 - Project Management: J. A. Campbell}

Plan, coordinate, and control the activities associated with the analysis of the C-103 dip sample. Activities include preparing and issuing a project statement of work (SOW), preparing and issuing a management plan, preparing a quality assurance plan with support from PNL QA staff, managing costs 
and schedules, and maintaining liaison with the WHC. A report summarizing the results of the analysis of the dip sample will be submitted to WHC. A final report containing all of the analytical data will be submitted for clearance.

\section{Task 0402 - Analysis of Dip Sample}

This task is divided into seven subtasks. Each category is described below.

\section{Subtask 040201 - Organic Analysis; Task Manager: J. A. Campbell}

Organic Phase (Organic Phase Component Enrichment). The organic phase, if not radioactive, will be diluted if necessary, and analyzed by GC/MS. If the major component is NPH, further separation by fractionation may be required. Techniques have been developed to separate NPH from both volatile and semivolatile components. This phase will allow minor components to be identified. If the sample is non-radioactive, an infrared analysis will be performed to help identify major and minor components. Use of selected drying agents may be incorporated to separate the radionuclides from the bulk of the organic portion, assuming that the radionuclides are water soluble.

If the organic phase is radioactive, distillation to isolate the activity may be required either in the hot cell or hood. Distillation will also be used to separate NPH from the fraction. Several fractions with the following approximate boiling point ranges of $45-65^{\circ} \mathrm{C}, 65-85^{\circ} \mathrm{C}$, and $85-120^{\circ} \mathrm{C}$ will be collected and analyzed by GC/MS. In addition, the radioactive residue left after distillation will also be analyzed.

An aliquot of the organic phase will be heated in a flask equipped with a reflux condenser. The sample will be heated to approximately $40^{\circ} \mathrm{C}$, which reflects the temperature of the tank, $70^{\circ} \mathrm{C}$, and $100^{\circ} \mathrm{C}$. The gas phase above the liquid and the non-condensable gas in the reflux condenser will be sampled for each of the test runs $\left(e . g ., 40^{\circ} \mathrm{C}, 70^{\circ} \mathrm{C}\right.$ and $100^{\circ} \mathrm{C}$ ) and analyzed using $\mathrm{GC} / \mathrm{MS}$. Three measurements at 2 -hour intervals, or the time requirement for equilibrium to be established, will be needed. The gas phase above the liquid and non-condensable gas in the reflux condenser will be sampled by summa canister and solid adsorbent methodologies. Samples will also be taken and analyzed using Fourier transform infrared spectroscopy (FTIR). The concentration of ammonia and alkyl nitrates will also be measured.

Alkane nitriles (potentially toxic components) are suspected trace components in the organic phase of $\mathrm{C}-103$. Microdistillation techniques will be utilized to isolate and concentrate the fraction containing the nitriles. However, distillation may provide a fraction that may be contaminated with components that have similar boiling points, (e.g., NPH). If necessary, PNL will apply preparative high-performance liquid chromatography (HPLC) separation to isolate the alkane fraction from the interfering NPH matrix. This procedure will allow for a chemically less-complex subfraction that will enable more detailed characterization of trace-level components. The method of separation proposed utilizes 
normal phase HPLC with an amino column. This method was developed by PNL and is applicable for primary, secondary and tertiary amines in coal liquids. The applicability to alkane nitriles in NPH will be demonstrated.

\section{Subtask 040202 - Organic Analysis of Aqueous Phase; Task Manager: J. A. Campbell}

Aqueous Phase: The aqueous phase will be separated from the organic phase. In the aqueous phase, the sample will be acidified and eluted through a cation-exchange column and collected. This method has proved successful in removing the radioactivity without removing organic acids from the aqueous phase extraction of samples from tank 101-SY. Small organic acids will be analyzed using GC/MS, liquid chromatography (LC), or L.C/MS. Volatile analysis will then be accomplished by purge and trap GC/MS.

An aliquot of the aqueous phase will be analyzed for $\mathrm{pH}$; total inorganic carbon (TIC), hydroxide ion concentration; total gamma emission spectra (to obtain a qualitative radionuclide inventory), cations by inductively coupled plasma (ICP) emission spectroscopy, and anions by HPLC. The residue will also be analyzed using differential thermal analysis/thermogravimetric analysis (DTA/TGA) and for total organic carbon (TOC).

An aliquot of the aqueous phase will be heated in a flask equipped with a reflux condenser. The sample will be heated to approximately $40^{\circ} \mathrm{C}, 70^{\circ} \mathrm{C}$, and $100^{\circ} \mathrm{C}$. The gas above the liquid and the non-condensable gas in the reflux condenser will be sampled at approximately $40^{\circ} \mathrm{C}, 70^{\circ} \mathrm{C}$, and $100^{\circ} \mathrm{C}$ and analyzed using GC/MS. Three measurements at 2 -hour intervals will be needed. The gas above the liquid and the non-condensable gas in the reflux condenser will be sampled by SUMMA canister and solid adsorbent methodologies. Samples will also be taken and analyzed by FTIR. The concentration of ammonia will also be measured.

\section{Subtask 040203 - Measurement of Actinides in Organic Residue; Task Manager:}

\section{R. B. Strebin}

Robert M Marusich determined the following de-minimis activity for this study. The values, decreased by a factor of 10 to be conservative, are as follows. If the curie content of the transuranic (TRU) waste in the organic layer is less than $1 \mathrm{E}-8 \mathrm{Ci} / \mathrm{L}$ of TRU; $2.4 \mathrm{E}-5 \mathrm{Ci} / \mathrm{L}$ of ${ }^{90} \mathrm{Sr}$, and ${ }^{90} \mathrm{Y}$, and 2.4E-4 Ci/L of ${ }^{137} \mathrm{Cs}$; a detailed chemical analysis need not be done. Calculating the values for disintegrations per minute (dpm) gives the following: TRU, $22.2 \mathrm{dpm} / \mathrm{mL} ; \mathrm{Sr},{ }^{90} \mathrm{Y} 53,280 \mathrm{dpm} / \mathrm{mL}$; and ${ }^{137} \mathrm{Cs}, 532,800 \mathrm{dpm} / \mathrm{mL}$.

The following steps are taken to measure actinides in organic residue:

1. Screen to determine if alpha and beta levels are below the level of concern. 
These levels are within the capabilities of liquid scintillation counting (LSC) using alpha-beta discrimination. However, very high levels of beta can interfere with very low levels of alpha making some combinations of activity beyond the range of the determination. A $1-\mathrm{mL}$ sample would be analyzed.

A cesium determination would be made by gamma energy analysis. A gamma scan would be included giving the major gamma emitters. If the levels were above the levels of concern or beyond the capability of the LSC screening technique, step 2 would be carried out.

2. Determine if the alpha and beta levels are above the level of concern.

Another aliquot of sample would be needed. The aliquot would be solubilized using microwavepressure digestion to give a solution which would be subsampled for individual analyses. There is considerable uncertainty in this step due to unknowns about the sample matrix. It is very important to be assured that the sample is in solution prior to further work.

The gross alpha determination by LSC would be repeated. An actinide separation would be made, and, using alpha energy analysis (AEA), the ratios of the actinides (alpha emission ratio) would be given. ${ }^{241} \mathrm{AM}$ and ${ }^{238} \mathrm{Pu}$ overlap and could be separated if the percent of ${ }^{238} \mathrm{Pu}$ is known or can be estimated. If the gross alpha determination is beyond the range of the LSC, spikes would be used to quantify the TRU determination. A strontium determination would be made.

This work would be done on a best-effort basis, and charges would only be made for actual work done.

\section{Subtask 040204 - Water Content in Organic Phase; Task Manager: K. Pool}

The organic phase will be analyzed for water content. Samples of the immiscible organic layer taken from tank C-104 will be analyzed for water content by the direct-coulometric, Karl Fischer titration method. Each of the four samples will be analyzed in triplicate. Results for analysis of samples along with supporting quality control data (spike recovery, control standard recovery, blank(s)) will be reported to the PNL project manager.

Subtask 040205 - Flash-Point Analysis of Organic Phase; Task Managers: J. M. Robbins and D. R. Sanders

A PETROLAB 2-ml capacity, mini flash-point tester and accessories will be purchased. Since the purchase price is less than $\$ 10 \mathrm{~K}$, the instrument can be purchased without a formal bid process. Any delivery delays due to the PNL purchasing process will translate in a one-for-one slippage in the work schedule. 
A mini flash-point testing procedure, to substitute for the approved American Society for Testing and Materials (ASTM) 60-mL Pensky-Martins Closed Cup Tester, will have to be written prior to start of the analysis work. Procedure development work involves testing and calibration of a 2-mL, mini flash-point tester against the 60-mL manual Pensky-Martins Closed Cup Tester using standards and NPH mixtures.

Dip samples from the tank C-103 organic layer should be transferred to a metal or glass sampling container and packaged for shipment to PNL-Analytical Chemistry Laboratory (ACL). The tank C-103 oil-layer samples will be received in the PNL 325 Building Shielded Analytical Facility. A suitable aliquot will be transferred out of the cell and sent to a laboratory for flash-point analysis.

Therefore, flash-point apparatus will be operated in a hood and enclosed in a shield on three sides to eliminate air drafts over the instrument. Any contamination will be exhausted through a drier hose attached between the side exhaust of the flash-point tester and the rear-hood exhaust. The decision to place the instrument in a hood rather than in a hot cell is also based on past experience by the PNL Organic Analysis Group in analysis of the C-103 tank oil layer for semivolatile compounds. A 1-mL sample of oil was transferred out of cell and analyzed in hood (see Shielded Analytical Laboratory notes). For radiation work permit information, call D. M. Brehm or consult manual MA-6.

Samples will be pre-tested for flashing at room temperature prior to flash-point analysis. Instruments will be calibrated using n-dodecane. Samples will be analyzed as-is in triplicate because of concerns about the homogeneity of the sample taken from the C-103 tank. It is recommended that an additional aliquot be centrifuged to remove any water emulsion and the segregated organic layer analyzed as a worst-case flash-point scenario.

Inter-calibration will be completed against a GCA Precision Scientific manual Pensky-Martins Closed Cup Tester (Expense L551603). A draft procedure will also be completed, and D. R. Sanders will take the lead in writing the procedure, with J. M. Robbins reviewing the procedure and writing the final report of analysis.

The draft procedure will follow the analysis of tank C-103 dip samples.

\section{Subtask 040206 - Analysis of Inorganics; Task Manager: D. L. Baldwin}

Ion chromatography (IC) for anions and inductively coupled plasma (ICP). Sample preparation for IC for anions and ICP for cations may require extensive separation treatment work in the hot-cell facility. Various options include the following: 1) clean cut of organic/vacuum strip, dissolve; 2) extract aqueous phase into dilute nitric acid for separation; and 3) separation of aqueous/organic by centrifugation. The analysis of anions will include $\mathrm{Cl}^{-}, \mathrm{F}^{-}, \mathrm{NO}_{3}^{-}, \mathrm{NO}_{2}^{-}$, and $\mathrm{SO}_{4}^{--}$. Cations will be analyzed by $\mathrm{ICP}$ and include $\mathrm{Ag}, \mathrm{Al}, \mathrm{As}, \mathrm{B}, \mathrm{Ba}, \mathrm{Be}, \mathrm{Ca}, \mathrm{Cd}, \mathrm{Ce}, \mathrm{Co}, \mathrm{Cr}, \mathrm{Cu}, \mathrm{Dy}, \mathrm{Fe}, \mathrm{K}, \mathrm{La}, \mathrm{Li}, \mathrm{Mg}$, Mn, Mo, Na, Nd, Ni, Pb, Re, Rh, Ru, Sb, Se, Si, Sr, Te, Th, Ti, Tl, U, V, Zn, and P. 
Comments on the subtask are as follows:

1. All work will be performed at Impact Level III, to Good Practices Standard and MSC-033.

2. The work requires QC appropriate to GPS and MSC-033.

3. All waste is to be disposed of through normal laboratory means, either through each laboratory or through the Shielded Analytical Cells. If waste is EPA-listed, appropriate disposal must be done.

4. A sample of each layer (both organic and aqueous) will be archived for future use.

\section{Subtask 040207 - Rheological Analysis; Task Manager: J. Tingey}

The rheological analysis of C-103 dip sample will require a maximum 50-mL sample. The required sample volume will be reduced if the dose of a $50-\mathrm{mL}$ sample is less than $100 \mathrm{mR}$. This method does not destroy the sample, and the same sample could be used for other analyses.

The shear stress of the sample will be measured as a function of shear rate. The apparent viscosity of the sample will then be calculated at each shear rate and be reported as a function of shear rate. The apparent viscosity of the sample is the shear stress divided by the shear rate. The data will be compared to standard models, a curve fit obtained. This curve fit will model the shear stress as a function of shear rate.

The accuracy and detection limits that can be obtained are dependent upon the dose rate of the sample. For samples with low dose rates $(<100 \mathrm{mR}$ for a $50-\mathrm{mL}$ sample), the minimum viscosity that can be accurately measured is $1 \mathrm{cP}$. The accuracy of these measurements is $\pm 1 \mathrm{cP}$ or $10 \%$, whichever is greater. If the dose of the sample is $>100 \mathrm{mR}$ for a $50-\mathrm{mL}$ sample, the minimum viscosity that can be accurately measured is $3 \mathrm{cP}$. The accuracy of these viscosity measurements of high dose samples is $\pm 3 \mathrm{cP}$ or $10 \%$, whichever is greater. For low-dose samples, the temperature is $5^{\circ} \mathrm{C}$ to $95^{\circ} \mathrm{C}$. For high-dose samples, the measuring range of the sample is $30^{\circ} \mathrm{C}$ to $95^{\circ} \mathrm{C}$.

\section{Task 0403 - Analysis of PUREX Sample; Task Manager: J. A. Campbell}

A sample from the PUREX process containing predominantly NPH and TBP will be analyzed by GC/MS.

Preliminary Activities: Prior to the arrival of the sample, the apparatus that will be utilized for the gas-generation experiments will be evaluated with a simulated waste sample to solve any problems that 
may arise. In addition, the applicability of both summa (if the capability has been established) and adsorbent collection of volatile analytes will be evaluated with the simulate waste.

Milestones and Deliverables: A report summarizing the results of the analysis of the dip sample will be submitted to WHC. PNL will also publish a cleared report. 


\section{Distribution}

No. of

Copies

\section{OEFSITE}

12 DOE/Office of Scientific and

Technical Information

K. T. Lang

U.S. Department of Energy Headquarters EM/361 329 TREV

19901 Germantown Rd.

Trevion Bldg.

Germantown, MD 20874-1290

S. M. Blacker

MACTEC

8310 Center Brook Place

Alexandria, VA 22308

\section{QNSITE}

\section{DOE Richland Operations Office}

\section{J. M. Clark \\ R3-72}

21 Westinghouse Hanford Company

J. N. Appel

H. Babad

K. E. Bell

P. K. Bhatia

T. M. Burke

C. Defigh-Price

J. P. Harris

J. G. Hill

S. E. Kelly

J. J. McCown

G. T. MacLean

R. M. Marusich

D. M. Nguyen

A. F. Noonan

A. K. Postma

J. G. Propson
S4-58

R2-78

R2-12

S4-58

S4-58

R2-31

S4-55

R2-12

G6-08

B2-23

S4-58

H4-60

R4-03

R2-12

H4-62

R2-18
No. of

Copies
E. J. Shen
S4-58
D. A. Turner
R2-78
J. A. Voogd
H5-49
R. A. Watrous
G6-08
E. T. Weber
G6-08

Kaiser Engineers Hanford Company

D. J. Shrimpton

E6-21

Northwest Instruments

Mike Story

H5-09

42 Pacific Northwest Laboratory

C. M. Anderson K7-34

D. L. Baldwin P8-08

R. M. Bean P8-08

J. W. Buck K6-55

J. A. Campbell P8-08

P. J. Cowley K7-22

J. O. Heaberlin K8-41

P. G. Heasler K7-34

V. L. Hunter K7-94

V. P. Ostrander K7-73

M. S. Peffers K7-94

B. A. Pulsipher K7-34

J. L. Scott P7-34

D. M. Strachan K2-44

R. S. Strebin P8-08

P. J. Styris (15) K8-41

J. M. Tingey P7-25

R. S. Wegeng K7-97

C. E. Willingham K8-41

T. W. Wood K8-41

J. K. Young K8-11

Publishing Coordination

Technical Report Files (5) 


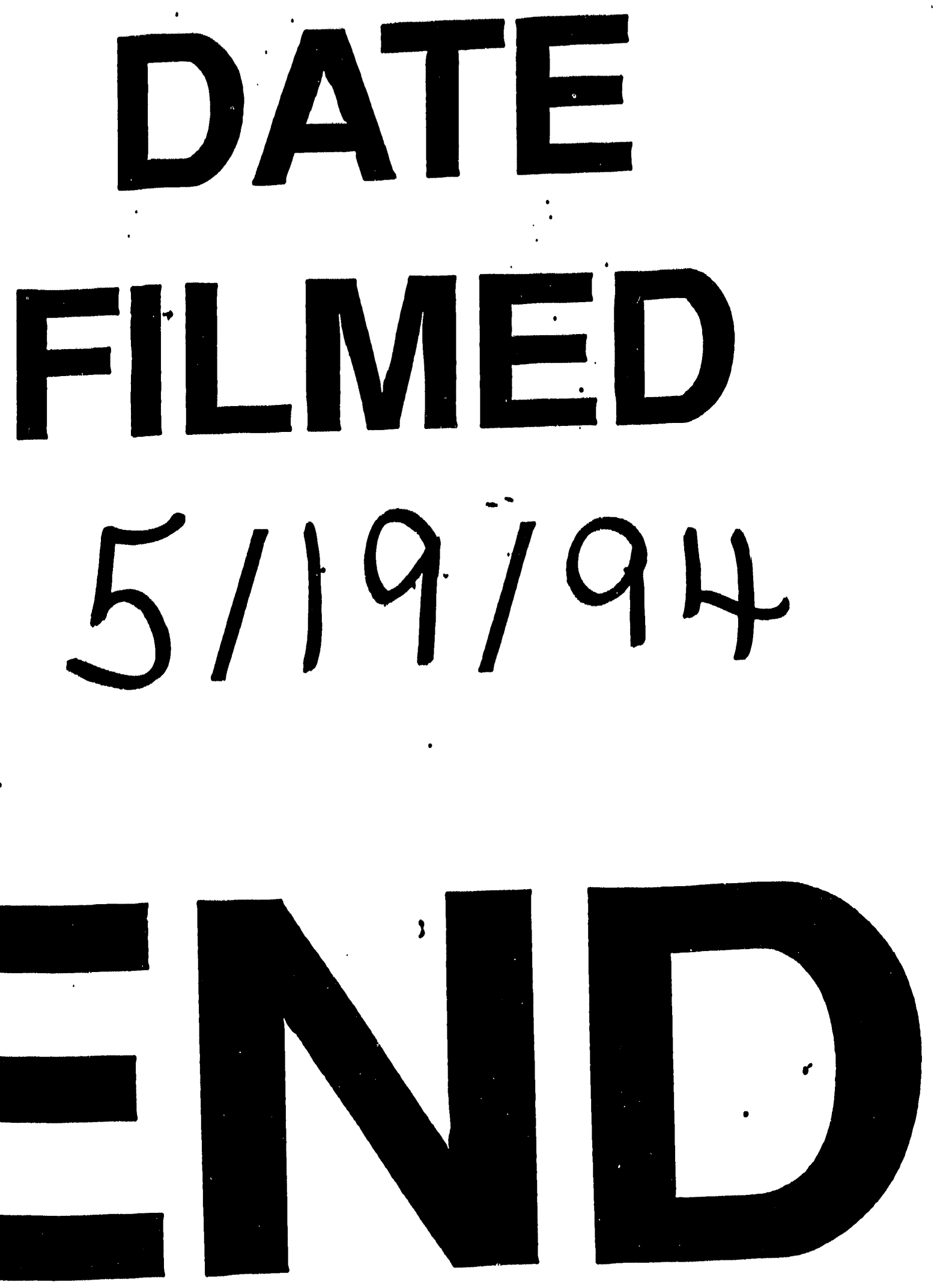




$$
\longrightarrow
$$

$-\ldots$

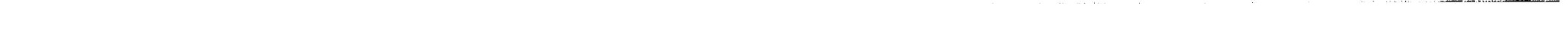

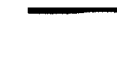

